\title{
MEDIA DISCOURSE, IDEOLOGY AND PRINT MEDIA IN TURKEY
}

\author{
Begüm BURAK \\ bgmbrk@hotmail.com \\ https://orcid.org/0000-0002-0071-7330
}

\begin{abstract}
This article addresses power, ideology and media context generally. .In democratic countries, the free media is regarded as the "fourth estate" besides the legislative, executive and judiciary branches. It can be said that political power has a significant role in shaping media discourse. The newspapers as the most efficient print media elements have an effective role in media discourse. Besides determining political agenda, the newspapers function as the instrument of hegemony of the political authority. The objective of this article is two-fold. The first is to analyze the role of the media discourse in the (re)production of ideologies. Within this framework, the role of the media in democratic countries will also be under scrutiny. Second,a historical overview of Turkish print media in general and the Hürriyet newspaper in particular will be provided. Bourdieu argues that, the power of the words lies not in their intrinsic qualities but in the belief that they are uttered by authorized spokespersons (Bourdieu, 1991: p.170). In this context, one of the main arguments of this article is that the Hurriyet newspaper as one of the leading voices of the mainstream media is efficient in determining the political and social agenda. The qualitative research method is used in the article.
\end{abstract}

Keywords: Ideology, power, media, media discourse, print media in Turkey

\section{MEDYA SÖYLEMI, İDEOLOJI VE TÜRKIYYE'DE YAZILI BASIN}

\section{ÖZ}

Bu makale genel olarak güç, ideoloji ve medya söylemini irdelemektedir. Demokratik ülkelerde özgür medya yasama, yürütme ve yargı erkinin yanında "dördüncü kuvvet" olarak görülmektedir. Siyasal gücün medya söylemini şekillendirmede önemli bir rolü olduğu söylenebilir. En etkili yazılı medya unsurlarından olan gazeteler medya söyleminde önemli bir role sahiptirler. Siyasal gündemi belirlemeye ek olarak gazeteler siyasal iktidarın hegemonya aracı olarak da işlev görmektedirler. $\mathrm{Bu}$ makalenin çift yönlü bir amacı bulunmaktadır. Birincisi, ideolojilerin söylemsel olarak üretilmesinde medya diskurunun rolüne ışık tutmaktır. Bu çerçeve içinde, demokratik ülkelerde medyanın rolü analiz edilecektir. İkinci olarak genelde Türk yazılı basını, özelde ise Hürriyet gazetesi tarihi bir özet ile analiz edilecektir. Bourdieu'a gore (1991, p. 170), kelimelerin gücü onların içkin özelliklerinde değil onların yetkin sözcüler tarafından ifade edilmesindedir. Bu bağlamda Hürriyet gazetesinin anaakım medyanın başat seslerinden biri olarak siyasal ve sosyal gündemi belirlemede etkili olduğu makalenin temel iddialarından biridir. Makalede nitel araştırma yöntemi kullanılmıştır.

Anahtar Sözcükler: İdeoloji, güç, medya, söylem, medya söylemi, Türkiye'de yazll medya

\section{POWER, IDEOLOGY AND MEDIA DISCOURSE}

Montgomery (1995: p. 251) argues that "language informs the way we think, the way we experience, and the way we interact with each other." Language use cannot be evaluated as a reflection of reality, it is in fact central to producing it. The words are not value-free, they reflect the authority and the interests of those who speak. "Language is not an isolated phenomenon; language is deeply social, intertwined with social processes and interaction." (Wodak, 1999: p.186). Habermas argues that language is a tool of domination. It serves to legitimize the authority of organized power (cited in Wodak and Meyer, 2009: p.10). 
Neil Thompson (2003: p.37) states that "language is not simply the ability to use words"; it "refers to the complex array of interlocking relationships which form the basis of communication and social interaction." Particularly, the language of the mainstream media is regarded as an arena of struggle and also as a platform where language is apparently transparent.

On the other hand, definitions of the term 'discourse' are numerous and generally not concrete. Most of the time, Foucault is regarded as the point of reference in understanding what discourse is. To him discourse is a specific form of the production of knowledge, especially the knowledge systems that constitute various sciences (Fairclough and Wodak, 1997: p.261). For Foucault (1979) discourses can be seen as some kind of knowledge systems in the human sciences such as linguistics that ultimately constitute power in modern society. Foucault puts stress on power struggle over the determination of the practices related to discourse. According to him (1984: p.110) "Discourse is not simply that which translates struggles or systems of domination, but is the thing for which and by which there is struggle, discourse is the power which is to be seized." Accordingly, media discourse is open to debate because the nature of the power relations carried out in it is generally not so clear.

In line to that, a discourse is seen as some sort of social practice, always determined by social rules and values, and social practices, and always delimited and shaped by power-related structures and historical processes (Wodak, 1995). Discourse-related practices can perform important ideological effects, that they can produce and/or reproduce unequal power relations between for example women and men, and ethnic/cultural minorities and majorities through the forms in which they represent things and position groups of different people (Fairclough and Wodak, 1997: p.258).

An account of ideology is an indispensable part of media studies while exploring how media discourse in general and news discourse in particular both reproduce and contest the existent power relations."Nobody," according to Terry Eagleton, "has yet come up with a single adequate definition of ideology." (Eagleton, 1991: p.1). However, academics and researchers usually are in agreement about the nature of ideologies, it is about social relations, and power struggle. The term 'ideology' refers to behaviours, set of beliefs, and values with reference to political, social, cultural and financial life, which influence the individual's perception and worldview through which reality is constructed. It is mainly in discourse that ideologies are transmitted.

Althusser's conception of ideology is important while analyzing how ideology is reproduced through discourse. Althusser's development of the concept of ideology differs from the traditional Marxist understanding of ideology as false consciousness. Althusser views ideology as a form of representations which masks our real relations with each other in society through building imaginary relationships among people (Althusser, 1971: p.162). Hence, ideology can be regarded as a distorted recognition of social relations. According to Althusser, each aspect of the social is controlled by ideology, which functions through 'the repressive state apparatus' (e.g. the armed forces) and 'the ideological state apparatus' (e.g. the media). (Jorgensen and Philips, 2002: p.15). Ideology can also be seen as a channel through which the ruling elite tries to deceive and control the ruled groups. With reference to J.B. Thompson (1984: p.4) ideology is "linked to the process of sustaining asymmetrical relations of power-to maintain domination... by disguising, legitimating, or distorting those relations."

It can be said that, ideologies often appear in polarized thought, opinions, or discourses where prejudice is evident through a positive representation of the self (the in-group; 'Us') and a negative representation of the other (the out-group; 'Them'). The major ideology plays a key role in the production of media discourse and this tells about why the media can be expected to work as an instrument of justification.

According to Gramscian perspective, ideology often works through common sense. A. Gramsci outlines the main characteristics of common sense as the perception of the world which is uncritically accepted by a variety of social and cultural elements through which the moral individuality of the 
average man is constructed. Common sense is not a unique concept, identical in space and time (Gramsci, 1971: p.419). Following this, it can be said that the media play the role of maintaining the dominant ideology through creating some sort of common sense.

The news in the media as a specific type of media discourse does not reflect merely reality, hence, it should be noted that the news discourse is not a means to an end, i.e. delivering information. News reporting is socially created; therefore the events that are reported are not a reflection of their importance but reveal the ideology of the news reporter.

With the work of Habermas (1989) the emergence of the newspaper has been treated as a central institution of the public sphere and democratic discourse. Nevertheless, the newspapers present the news most of the time in a way that aims to shape the ideological attitude of the reader. Newspapers also contribute to the reproduction or legitimization of power of elites and reproduce the attitudes of the powerful.

In order to reproduce the dominant ideology, media representations may involve stereotyping, discrimination or exclusion. Media from time to time may enact symbolic violence involving the use of derogatory vocabulary, vilification, dehumanizing phrases, abusive words or marked expressions. Pierre Bourdieu defines symbolic violence as a situation when "one class dominates another by bringing their own distinctive power to bear on the relations of power which underlie them and thus by contributing, in Weber's term to the "domestication of the dominated" (Bourdieu, 1991: p.167). Through using particular discursive strategies, the positive self-representation and negative otherrepresentation are employed in enactment of symbolic violence.

On the other hand, a brief conceptual analysis of power is essential for understanding the function of news discourse in the providing the unequal power relations. Media representations cannot be adequately analyzed without a conception of power. It can be said that language reflects power, and it is exercised where there is contention over power and a challenge to power (Wodak and Meyer, 2009: p. 10).

There are different forms of power. The coercive form of power depends on force, the persuasive form of power of for example professors or journalists may be based on knowledge or authority. Dominated groups may resist, accept, comply with or legitimate such forms of power, and even can take it for granted. As a matter of fact, the power of dominant and groups are integrated in norms, legal rules, habits and even a consensus, and thus take the form of what Gramsci called 'hegemony' (Gramsci, p. 1971). Racist and the sexist discourses are characteristic examples of such a form of hegemony. Hegemony depends on a combination of force and consent but it is more effective when consent is obtained through the unquestioned acceptance of ideology by the governed. Hegemony is related with the instruments and processes by which knowledge and beliefs are built, and disseminated with the aim to maintain and/or exercise the rule of the elite (the dominant group) by gaining the consent of the masses (Fontana, 2005: 98).

It is to be noted that, the representation through the media cannot be free from struggle. The media can be used as an instrument for (re)producing the hegemonic discourse. Torfing (1999: 220) writes that a hegemonic discourse "establishes a truth regime that defines what can be considered true and false and a value regime that provides criteria for judging what is good and bad."

Stuart Hall analyzed how media institutions fit into this view of hegemony. For Hall the mass media are one of the significant platforms where the cultural dominance, in other words hegemony is performed. Media discourses are used in what Hall calls 'the politics of signification', in which the media produce scenes of the world that attach particular meanings to events. These images do not simply reflect the world, they re-present it. As Hall (1982: p. 64) writes "Representation is a very different notion from that of reflection. It implies the active work of selecting and presenting. "The media representations are intertwined with problematizations of ideology and power because the 
process of attaching meaning to events reveals that, there are various ways to define reality. Media have, as Hall (1982: p. 69) says, "the power to signify events in a particular way."

As mentioned earlier power plays a key role in media-politics relations. Foucault's approach to power is useful in analyzing power/knowledge relationship with regard to media discourse. After the publication of The Archeology of Knowledge, Foucault became interested in the relationship in between power and knowledge. For him: "power and knowledge directly imply one another (...) there is no power relation without the correlative constitution of a field of knowledge.." (quoted in Oberhuber, 2008: p.277). Power, in Foucault's view, is inseparable from knowledge.

The Foucauldian notion of power argues that 'power is everywhere', embodied and diffused in discourse, knowledge and 'regimes of truth'. For Foucault, power should not be regarded as exclusively oppressive but as productive that constitutes discourse and knowledge. Foucault argues that power is diffuse rather than concentrated, discursive rather than merely coercive (Gaventa, 2003: p.1). That kind of power for him categorizes the individuals and attaches them to their own identity. It is a form of power which turns individuals to subjects.

Power in modern societies is persuasive rather than coercive such as the explicit issuing of commands, economic sanctions or threats. In this regard, media discourse plays a key role in 'manufacturing consent' (Herman and Chomsky, 1988). Media power is generally persuasive, in the sense that the media mainly have the potential to control to some extent the minds of the audience. A significant concept in the analysis of media power is that of access. Access to discursive and communicative events may take a variety of forms. More powerful players may control discourse by constructing or selecting time and place, participants, audiences and the choice of language which will be used (Ibid: p.12). In this sense, it could be said in a similar way to the argument of Chomsky and Herman (1988) that the views of the powerful are expressed more frequently in the media and they are represented as the primary sources in many cases (Fairclough, 1995: p.2,5,40,55; Fowler,1991: p.105,109). In line to that, Herman and Chomsky (1988: p. xi) adhere to the view that the mass media are tools of power which "mobilize support for the special interests that dominate the state and private activity."

\section{THE ROLE OF THE MEDIA IN DEMOCRATIC COUNTRIES}

The countries which have democratic regimes are defined by a commitment to rule by the people, limited government and representative political institutions. Democratic governments consist of a demanding political system, not just a mechanical condition like the majority rule taken in isolation. Democracy requires the active participation of the citizens. In line to that, the media should make citizens (the public) become aware of the business of governance by educating, informing and mobilizing them. In a democratic society, the media aim at informing the citizens about processes of taking decisions and making them alert in order to provide their active participation in policy-making processes.

The role of the media in a strong democracy has been underlined centuries ago when the 17th century Enlightenment thinkers had argued that openness provides the best way for the protection against tyrannical rule. The French philosopher Montesquieu prescribed openness as the cure for the abuse of political power. The English and American theorists later in that century would agree with Montesquieu, seeing the importance of the press in making the ruling elites become aware of the public's discontents and demands (Holmes, 1991: pp.21-65). According to this understanding, the press/media has been widely regarded as the 'Fourth Estate' as a tool that provides the check and balance system without which governments cannot be successful. In addition to that, the press has been regarded as an important instrument that educates and informs citizens. The press creates in Habermas' (1989) words, public spheres which not only provide information but which also serves emancipation. On the contrary, Althusser rejects such an emancipatory role of media. Althusser maintains that in capitalist systems, freedom is an ideological creation serving the interests of the elites. 
Related to the function of the media in a democratic country, J. Keane (1991) states that the liberal economy has a negative impact on the quality of democracy. Keane summarized this argument about neo-liberalism in the media sector stating "time has long passed when it could be assumed credibly that market competition guarantees freedom of communication." (Keane, 1991: p.88-89).

Patrick H. O'Neil who constituted an analytical toolkit for the analysis of the relationship between the mass media and the stages of political transition and democratization argues that contribution of the mass media to the democratization process depends on "the form of and the function of media in a given society, shaped by cultural, socio-economic and political factors."(O’Neil, 1998: p.7).

There is a variety of democratic functions that the mass media perform. These functions include surveillance of sociopolitical developments, constituting a platform for debate across a diverse scope of views, identifying the most relevant issues, and building stimulators for citizens to learn and get involved in the political processes. In a similar vein, it can be said that the newspapers under a democracy have three fundamental functions. They act as a watchman, as a policy shaper (introducing ideas and channeling debates), and as a teacher (providing opinions and information).

There are three important ways through which the mass media can shape values and the political situation: by affecting the public preferences and norms; by shedding light on elite thinking; and by working as an arena for the formation (change/maintenance) of elite thinking (Somer, 2010: 558). Elites in particular can put pressure on the media and control media discourse by using their political power. They may also attempt to restrict freedom of press by using the label 'reasons of national security'. In addition to that, they may put financial pressure on media companies. This kind of restriction can be observed in generally democratically-weak countries.

On the other hand, it is argued that the commercial media which operates according to the commercial rules and dependent on the ads for its income has become an antidemocratic force supporting the status quo as a result of being controlled by a few multinational conglomerates. It has been argued that the mass media via its commercialization has not served public interest as it should do in a democratic society. It is argued that people's worldviews are always shaped by media institutions guided by commercial concerns, which usually serve the interests of the elites. The misrepresentation and underrepresentation of the economically weak and/ or minority groups can be seen as a threat to democracy and civil liberties.

\section{AN OVERVIEW OF TURKISH PRINT MEDIA}

The establishment of the print media in modern Turkey is drawn from the late Ottoman times. In both the Ottoman Empire and the Turkish Republic, journalists played a major role in the transmission of Western values to the whole society.

According to Ragip Duran, Turkish media lean on the military elites and the big capital owners. In that sense, one of the most significant features of the Turkish media has been its dependence on the political and economic power. The media in Turkey has always had close relations with the politicalideological-military elites. This is also similar for the international arena; the media has advocated the most powerful states. According to some scholars, the media in Turkey do not represent the Turkish society (the average citizen), the Turkish media represents the Turkish sovereign class. It is the spokesman of the minority (Duran, 2003: p.71).

In the post-1980 period, as a result of the introduction of free-market economy, the private-run media institutions have started to challenge the official discourse. As a result of the liberalization steps which were taken in the 1980s, Turkey's media scene if not qualitatively, in quantitative terms has greatly expanded (Sezgin and Wall, 2005: p.789). Within the context of these changes, the press has become an important tool, not just for political actors but for corporate owners. 
The Doğan Group ${ }^{1}$, which owns important newspapers like the Hürriyet, Milliyet, Radikal, and boulevard daily Posta along with various other publications, several publishing centers and TV channels is the largest group in Turkish media landscape. On 14 February 2002, the Economist introduced Aydın Doğan to its readers as the 'Turkish Rupert Murdoch' .Established in 1980, the Doğan Media Group is the one and only media group that achieved fully vertical and horizontal integration in Turkey. The Doğan Media Group has a great market share in media sector.

On the other hand, despite the existence of the developments in printing technology and the in the presentation of the newspapers, overal readership of newspapers had stagnated until the mid 1980s. In fact, the people have never been interested in reading newspapers in Turkey. Favorable demographic factors such as high population growth, and the rise in urbanization rates did not change that reality (Kaya and Çakmur, 2011: p. 525).

It should also be noted that, in Turkish media scene, the pro-government entrepreneurs have experienced a certain degree of opportunity under the Justice and Development Party rule rule. This caused voicing criticisms against the government among the Doğan Media Group outlets. In September 2009 the Doğan Media Group was accused of tax dodging and charged with a fine of $\$ 2.5$ billion. Despite statements from the government that this was only a matter of tax punishment, there were concerns that the government was trying to opress the press ${ }^{2}$.

Indeed, generally-speaking, the institutional and legal arrangements in Turkey have not paved the way for the emergence of a plural and liberal environment for journalists. It should also be noted that, through the 1990s Turkey had been criticized by several human-rights organizations for imprisoning journalists. As a consequence of Turkey's official candidacy for the European Union in 1999 and with a new legislation in line with the EU requirements, press restrictions have been eliminated partly.

\section{THE HURRIYET NEWSPAPER}

The reason why Hürriyet is under analysis in this article is the reason that it is the best-selling daily in Turkey. 'Hürriyet' literally means freedom. In 1860s, Namık Kemal along with ZiyaPaşa published a paper against the monarchy called Hürriyet. In 1948 SedatSimavi released his last medium patent with the same name though there is no institutional relationship with the former newspaper (Özerkan, 2009: p.54).

Sedat Simavi underlined that the power of Hürriyet derives from her own economic resources that is why they do not have any fear that they can worry someone as well as having no need to please anyone else. In 1994, Aydın Doğan bought Hürriyet newspaper. In a column titled, 'Hurriyet is Different, Hürriyet is Big' Ertuğrul Özkök declared that Hürriyet will walk her path with the Doğan Group from then on and Hürriyet will keep on being a big and influential newspaper. ${ }^{4}$

Ertuğrul Özkök who is still working as one of the leading columnists of the newspaper had been the editor-in-chief between the years 1989-2009. After Özkök, Enis Berberoğlu has worked as the chief editor for five years. Currently, Sedat Ergin is the chief editor. Sedat Ergin became the chief editor of Hürriyet in August 2014. Before, respectively, Nezih Demirkent, Çetin Emeç and Ertuğrul Özkök have been the most influential chief editors of Hürriyet.

\footnotetext{
${ }^{1}$ The Doğan Group runs her activities in a variety of sectors. Thetrade, tourism, industry, finance, energy and media sectors are among these sectors.

${ }^{2}$ See for example "Dogan v.s. Erdogan Turkey's biggest media group gets a colossal tax fine" http://www.economist.com/node/14419403 (27.08.2013)

${ }^{3}$ The Hürriyet Newspaper, May 1, 1948.

${ }^{4}$ The Hürriyet Newspaper, July, 1, 1994.
}

Research Article - Submit Date: 03.01.2018, Acceptance Date: 06.03.2018 
Hürriyet is one of the biggest mainstream quality broadsheet newspapers with a circulation near to 350,000 copies per day. ${ }^{5}$ The conceptualization of 'admiral ship' can be seen as a metaphor which emphasizes the pivotal role that the newspaper has in Turkish politics. A book published for the 50th anniversary of the newspaper was named as the 'log book of the admiral ship'.Taha Akyol who started writing for Hürriyet in 2011 used this metaphor of 'admiral ship' in his first column. The title of Akyol's column was 'At Admiral Ship' which revealed how glad Akyol was to write for the admiral ship of Turkish press. ${ }^{6}$

Hürriyet has developed its own evolution in parallel to the development of the politics and economy of Turkey. Hürriyet ${ }^{7}$ was also the first newspaper through which technological developments were introduced to Turkish print media. When two correspondents of the newspaper went to the London Olympics in August 1948, it was the first time that Turkish readers saw the news of Olympics so quickly and with so many lively pictures (Özerkan, 2009: p.56). As has been mentioned earlier together with Milliyet which was bought by Aydın Doğan in 1979, Hürriyet marked the shift from ideological journalism to mass journalism in Turkey.

According to Tunç (2010: p. 646), "Hürriyet as the flagship newspaper of the DMG follows a strongly nationalistic, pro-army, secularist editorial line mostly through the writings of its columnists." Although the newspaper did not take a clear stance towards any political group within the transition process to multiparty system, it did not compromise from its 'nationalistic' flavor during the Cyprus crisis of the time.

It has been argued that Hürriyet is the newspaper of the state establishment. Accordingly, Mehmet Ali Birand (1941-2013) a renowned journalist who had worked as a columnist for the Doğan Media Group newspapers for several years had also supported the view that Hürriyet belongs to state establishment. Birand said the following: "While saying that it is a state newspaper, I do not mean that it is bought by the state elites. But it is the State. It does anything for the State. Hürriyet is a newspaper which works for the state. Whatever it takes, it always works for the state." (quoted in Özkır, 2013: p.60).

The argument stating that Hürriyet belongs to state establishment is also vocalized by Dinç Bilgin who had been one of the important media bosses of Turkey. Dinç Bilgin after leaving the media sector has implicitly and explicitly stated that Hürriyet and the military elites have a close relationship (cited in Özkır, 2013: p. 61). One of the actors of the 1960 coup government which were known for their opposition to the Democrat Party rule and for their support of a possible military takeover Orhan Erkanl, in the following years became the chief editor of Hürriyet from 1968 to the early 1970s. This development can also be viewed as an indicator of the depth of the relationship between the Hürriyet and the military elites.

The below figure is the cover page after the 27 May 1960 coup d'état. Despite some exceptional commentaries and columns, the editorial content of the Hürriyet newspaper during and after each military coup legitimized the army's intervention into politics (Özerkan, 2009: 65). Some of the headlines during the 1971 military rule exemplify this stance: 'People applauded the commanders', (Halk Komutanları Alkışladı) 'The Commanders received news of a counter-communist coup' (Komutanlar Komünist Darbe İhbarı Almışlardı) (Efe, 2012: p. 82). However, it should be noted that, Turkish EU membership process has also been supported by the newspaper. The paper announced the 1963 Ankara Agreement from the headline.

\footnotetext{
${ }^{5}$ The exact number was 314.387 (http://www.medyatava.com/tiraj (circulation between November13 and November19 2017)

6 “Amiral Gemisinde" http://www.hurriyet.com.tr/yazarlar/18903157.asp (15.10.2014)

${ }^{7}$ On the web page of Hürriyet it says : "As part of the globalization and changing journalism aproach and Hürriyet's 'continuous interaction with readers and stakeholders in every platform' attitude, Hürriyet is now proud to receive 6.8millionvisitseveryday in 65th year of its history through its newspaper, web, tablet and mobile channels." http://www.hurriyetkurumsal.com/Default.aspx?1g=ENG (19.08.2013).
} 


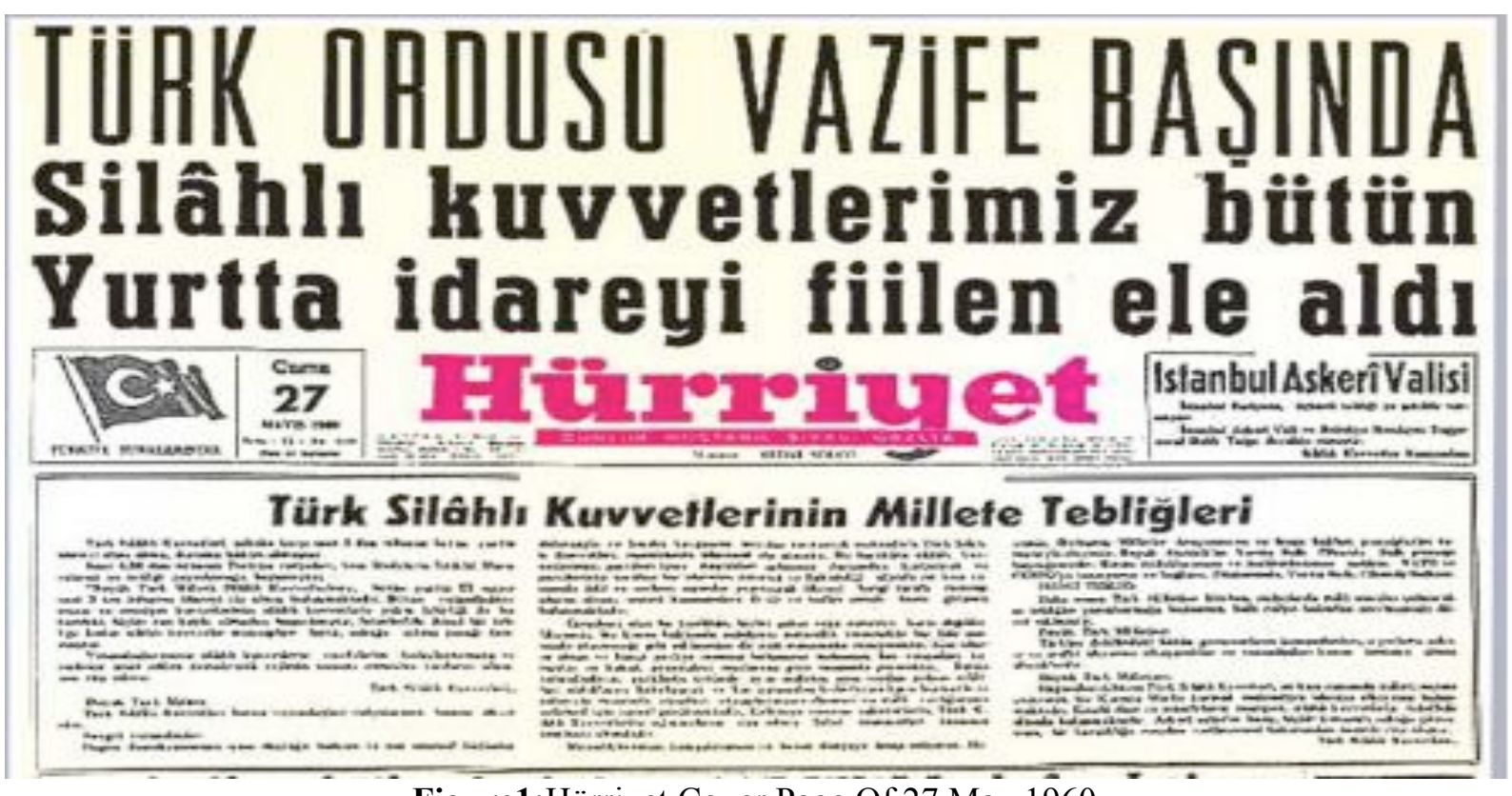

Figure1:Hürriyet Cover Page Of 27 May 1960

(The HeadlineTranslates: TheTurkish Army Is On Duty, Our Armed ForcesTook De Facto Control Of The Whole Country)

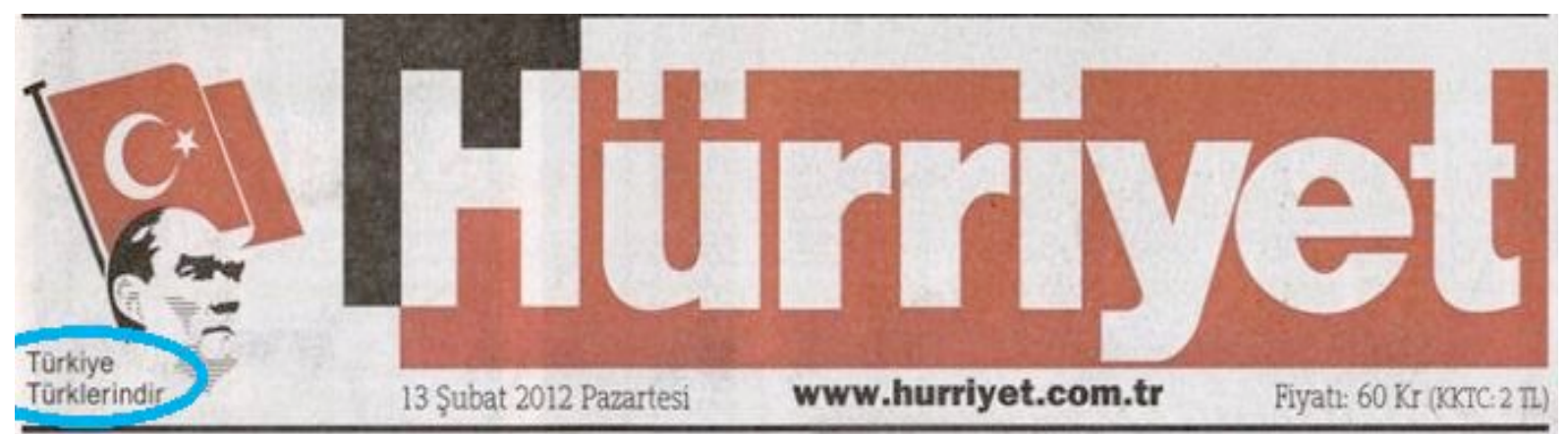

Figure2:The Logo and Slogan of Hürriyet

The slogan next to the logo of the newspaper which reads 'Türkiye Türklerindir' (Turkey belongs to Turks) has been used since 1950. This slogan is seen as racist and is heavily criticized by some circles $^{8}$. Aydın Doğan as the owner of the newspaper states that the main policy of Hürriyet is to protect the indivisible character of the country as well as protecting the primary principles of the Republic.

The Hürriyet newspaper has played a pioneering role in transmitting the Kemalist worldview to the masses through promoting a Western-oriented life-style. This promotion is evident in both the editorial content and the advertisements of the paper. For example, there are many alcohol beverages in the advertisements. Accordingly, it can be said that the newspaper has strictly defended that the Kemalist revolutions must not be abused by politicians (Topuz, 2003: p.214). With its English sister, the Hürriyet Daily News, the Hürriyet newspaper has always carried out an undisputedly important role through shaping the agenda on many political, economic and social issues in Turkey.

\footnotetext{
${ }^{8}$ One of theleadingfigures Sirr1 Sak1k in thePeaceandDemocracyPartyarguedthatthe slogan of Hürriyet is ratherracistand monist. He recommendedthatthenewspapershouldturn her slogan into "Turkeybelongstothepeoples of Turkey"http://www.gazeteciler.com/gundem/bdp-hurriyete-yeni-bir-slogan-onerdi-63269h.html (15.08.2014)
}

Research Article - Submit Date: 03.01.2018, Acceptance Date: 06.03.2018

DOI NO: 10.17932/IAU.EJNM.25480200.2018.2/2.53-62

Copyright (C) e-Journal of New Media 


\section{CONCLUSION}

In the conclusion part, I will try to examine the interaction between the ideology and the media discourse (mainly that of the Hurriyet) mainly from a historical perspective in addition to providing a brief summary of the study. The main concern of this study has been to explore the role that the print media play in shaping the ideology and the political environment in Turkey. Thus, some of the parts above were attempts to analyze the notions of "power, discourse, ideology" in an analytical way. To serve this aim, I applied important figures in political science such as Gramsci, Foucault, and Bourdie. In addition, I mentioned the historical context of media-politics relations a bit.

The relationship between the political apparatus, namely the elected and the appointed elites and the media has been quite problematic in Turkey. As known, in the late Ottoman times, censorship was witnessed to a great degree. In a similar vein, with the inception of the Republican regime, the founding father Ataturk and his close associates used the media as a tool in shaping the ideological understanding of the masses besides motivating them during the National Independence process.

On the other hand, after the introduction of multi-party politics, the political pressure put on media was one of the factors that eroded the legitimacy of the Democrat Party rule. It is also known that, some particular news fabricated against A. Menderes, the leader of the Democrat Party and that development had eroded his legitimacy as well. And as a result, the 1960 military coup took place.

Another important military coup in Turkey, the 1980 coup paved the way for the closure of some communication tools like that of newspapers. This also shows the critical role the media performs in a society in the eyes of the elites. Shortly, it can be argued that, the discourse that the media employs or the presence / absence of media autonomy shape the political and ideological settings of a country, and Turkey is a good example of that.

Another good example revealing how media discourses have shaped the policy and the ideology of the ruling elites in Turkey is the February 28 Process (1997). It is a widely known fact that, the media along with some particular non-governmental organizations played a critical role in undermining the legitimacy of the government besides portraying the public visibility of Islam as a threat to the secular nature of the regime. The debates regarding this process still dominate the socio-political landscape in Turkey.

On the other hand, the analysis of the structural and financial bases of the media outlets in a country is key to understand how media-politics relations affect the ideological debates and the situation of democracy. According to Lasswell (1948: p. 51) communication has the triple role of surveillance of the environment, the correlation of the elements of society in providing response to the environment and transmission of the social inheritance. Hence, the financial and structural bases of the Hurriyet newspaper which plays a key role in Turkish media landscape and has a unique character in spreading the official ideology (Kemalism) through the history of modern Turkey have been the main research topic in this article to explore the role of newspapers in affecting the political actors.

Finally, it can be argued that, in democratic countries, the free media is regarded as the "fourth estate" besides the legislative, executive and the judiciary branches. It can also be stated that political powerholders have got a significant and dynamic role in shaping media discourse. The newspapers as the most efficient print media elements have a significant role in media discourse. In addition to determining the political agenda, the newspapers function as the instrument of hegemony of the political authority. They produce an important amount of legitimacy. They help the political actors win/ lose elections besides stigmatizing some particular societal or political groups as "enemies". This study can be seen as an attempt to analyze all these points mainly from a historical perspective along with shedding light on significant academic figures like that of Gramsci and Foucault while exploring the topic under scrutiny. 


\section{REFERENCES}

Althusser, L. (1971). Ideology and Ideological State Apparatuses.New York: Monthly Review Press. Bourdieu, P. (1991). Language and Symbolic Power. Cambridge, Mass.: Harvard University Press Burak, B. (2010). Türkiye’nin Siyasal ve Yönetsel Yaşamında 28 Şubat Süreci'nin Yeri Üzerine Bir Inceleme (Master Dissertation, Istanbul University).

Duran, R. (2003). Türk Medyası Neden Savaş Yanlısı. Savaş ve Medya. Eskişehir: ILAD.

Eagleton, T. (1991). Ideology: An Introduction. London: Verso.

Efe, I. (2012). Critical Discourse Analysis of Kemalism and Islamism in Turkish Newspapers: The 2008 Indictment Case the 28 February National Security Council Meeting (Doctoral Dissertation, Lancaster University).

Fairclough, N. L. Wodak .R. (1997). Critical discourse analysis. In, Teun A. V. D.Discourse Studies. A Multidisciplinary Introduction. Vol. 2. Discourse as Social Interaction. London: Sage. 258-284

Fontana, B. (2005). The Democratic Philosopher: Rhetoric as Hegemony in Gramsci, .ItalianCulture.Vol: 23. No: 1. .97-123.

Foucault, M. (1979). Disciplin eand Punish: the Birth of the Prison. Harmondsworth: Penguin

Foucault, M. (1984). The Order of Discourse. In Shapiro, M. Language and Politics. London: Blackwell. 108-138.

Gaventa, J. (2003). Power After Lukes: A Review Of TheLiterature. Brighton: Institute of Development Studies

Hoare, Q., Geoffrey, N.S. (1971). Selections from the prison notebooks of Antonio Gramsci.New York: International Publishers.

Gurevitch, M.,Levy, M. R. (1985). Mass Communication Review Yearbook. Sage Publications Inc. Habermas, J. (1989). The Structural Transformation of the Public Sphere. Cambridge:PolityPress.

Herman, E. S. and Chomsky, N. (1988). Manufacturing Consent: ThePoliticalEconomy of the Mass Media. New York: PantheonBooks.

Holmes, S. (1991). Liberal constraints on private power? in Lichtenberg, J. Democracy and theMass Media. Cambridge: Cambridge UniversityPress. 21-65.

Kaya, R. Çakmur, B. (2010). Politics and the mass media in Turkey. Turkish Studies. Vol: 11. No:4. $521-537$.

Keane, J. (1991). The Media and Democracy. Cambridge: PolityPress

Lasswell, Harold D. (1948). "The structure and function of communication in society". in Bryson, L. (ed.). The Communication of Ideas. New York: Harper \& Co. Pp. 37-51

Montgomery, M. (1995). An Introduction To Language AndSociety. London: Routledge.

Patrick H, N. (1998). Democratization and MassCommunication: What Is the Link. inO'Neil, Patrick H. Communicating Democracy: The Media \&Political Transitions.London: Lynne Rienner Publishers. Özerkan, Ş.(2009). Haber Analizi Ve Arşiv Incelemeleriyle Türkiye'de 9 Gazete. Ankara: Nobel Yayin Somer, M. (2010). Media Values And Democratization: What Unites And What Divides ReligiousConservative And Pro-Secular Elites?.Turkish Studies. Vol:11. 555-577

Thompson, J. B. (1984). Studies in The Theory Of Ideology. Cambridge: Polity Press.

Topuz, H. (2003). II. Mahmud'tan Holdinglere Türk Basin Tarihi. Istanbul: Remzi Kitabevi.

Torfing, J. (1999). New Theories Of Discourse: Laclau, Mouffe And Zizek. Blackwell Publishing Ltd.

Tunç, A. (2010). Mediated Justice: Turkish Newspapers' Coverage of Controversial Criminal Cases. Turkish Studies. Vol: 11 No:4. 643-661.

Wodak, R. (1999). Critical discourse analysis at the end of the 20th century. Research on Language \&Social Interaction Vol: 32. No: 1-2 185-193.

Wodak, R. Michael, M. (2009). Methods for Critical Discourse Analysis. London: Sage. 